\title{
EFFECT OF SCOUTING EXTRACURRICULAR TOWARD CHARACTER VALUES OF STUDENTS AT SDN GEDANGANAK 01 DISTRICT EAST UNGARAN, SEMARANG REGENCY
}

\author{
Melyani Sari Sitepu ${ }^{1}$, Juli Maini Sitepu ${ }^{2}$, Satrio Wicaksono ${ }^{3}$ \\ Department of Primary School Teacher Education, the Faculty of Education, \\ University of Muhammadiyah Sumatera Utara \\ melyanisari@umsu.ac.id
}

This research is motivated by the problems of the low value of the student's character on SDN Gedanganak 01, which does not use attributes complete when the flag ceremony, taking out the trash is not in place, students who do not do their homework. The formulation of the problem is whether scouting extracurricular effects on the character values of elementary school students. This study aims to determine the effect of scouting extracurricular on the character values of the student at SDN Gedanganak 01, District East Ungaran. The method used is quantitative. The study populations were students of class IV and class V SD Negeri Gedanganak 01, with a total of 51 students. The data collection technique in this study was observation. Research hypothesis testing using t-test. The results showed the Scouting extracurricular effect on the character value of students at SDN Gedanganak 01. This is evidenced by the results of the analysis of the t-test is equal to 0.000 as a significant value. The significant value of $0.000 \leq \alpha$ (0.05). So the hypothesis which says scouting extracurricular effect to the character value of students at SDN Gedanganak 01, District East Ungaran, accepted

\section{Keywords: Scouting Extracurricular_Character Values}

\section{INTRODUCTION}

The scout movement is an organization formed by scouts to carry out character education (UU RI No. 12 of 2010: Chapter I article 1). This movement as a non-formal educational organization outside the school functions to accommodate aspirations in scouting. To make cadres active, creative, and intelligent, it is necessary for the scout movement to educate and train scout members.

The students in participating in scouting activities are required to comply with ten scouting obligations referred to as the Dasa Dharma, namely: (1) Piety to God Almighty, (2) Love for nature and compassion for humans, (3) Patriot who is polite and chivalrous, (4) Obedient and likes deliberation, (5) Willing to help and steadfast, (6) Diligent, skilled and happy, (7) thrifty, careful and modest, (8) Disciplined, brave and loyal, (9) Responsible and trustworthy, and (10) Pure in thought, word, and deed. Therefore, educational institutions, in this case, schools, have the responsibility to provide knowledge, skills and develop them both through formal and non-formal education. One of this non-formal education is through scouting education. Law number 12 of 2010 concerning the scouting movement chapter II article 3 concerning the functions of the scouting movement, namely: "Scouting education and training, scouting development, community and parental service, and games which education-oriented . "

Scouting activities can provide moral education and provide life values for the younger generation in an effort to provide character education. Scout education for students is a place for character building. This is in line with the mission of the scout 
movement in the context of educating and fostering Indonesian youth. The mission of scouting activities is to create development cadres, namely people who are Pancasila, honest, virtuous, skilled, intelligent, loyal to the state (Mukson, 2008: 4)

Character education is a solution for the Indonesian people in order to overcome the nation's moral decline, which is felt to be decreasing. Character education is the provision of various views of life values such as honesty, intelligence, caring, and others, and it is the choice of individuals that needs to be developed and needs to be fostered from an early age.

The phenomenon regarding the impact of the decline in character education can be seen from the uncharacteristic behavior that occurs in Indonesia. Such uncharacteristic behavior, for example, frequent brawls between students and between students, sexual harassment, and behavior like drinking and gambling. Even in some big cities, this custom tends to become a tradition and forms a permanent pattern, so that between them form mortal enemies. The rise of motorcycle gangs often leads to acts of violence that disturb the public and even criminal acts such as blasphemy, persecution, and even murder.

Scouting education has been carried out at SDN Gedanganak 01, East Ungaran District. Scouting education in this elementary school only prioritizes the scientific and intelligence aspects of students. The moral and ethical aspects as the basis for forming the nation's character and cultural values are increasingly marginalized. In addition, learning in the classroom is felt to be lacking in the formation of the character values of students. The teacher emphasizes the achievement of learning outcomes in the cognitive aspect so that the character values reflected in the students' attitudes do not appear.

Based on the results of observations, interviews at SDN Gedanganak 01, it is known that there are many deviant behaviors that occur in SDN Gedanganak 01 students. Deviant behavior that occurs in this school, for example, there are still many students who cheat on tests/exams, come to school not on time, do not obey the order or rules of the rules that exist in schools such as not wearing full attributes during the flag ceremony, throwing garbage out of place, bullying, students who don't do homework, students are still picky about friends in group work in class and lack manners in speaking and behaving. To the teacher. The mental condition, character, character, and morals of students who are concerned like this are deviant behavior, behavior that is not in accordance with the values of noble character, and behavior as if there is no positive legal order in accordance with the order of Indonesian cultural norms.

The existence of scouting extracurriculars is expected to form character values in students according to the nation's personality and avoid deviant behavior problems that occur in schools. These problems can be overcome by scouting education as a mandatory extracurricular. For this reason, a study was conducted that aims to determine "The Effect of Scouting Extracurriculars on the Character Values of Students at SDN Gedanganak 01, Ungaran Timur District, Semarang Regency, 2016-2017 academic year.

The formulation of the problem in this study is "Does scouting extracurriculars affect the character values of students at SDN Gedanganak 01, Ungaran Timur District, Semarang Regency? The purpose of this study was to determine the effect of scouting extracurriculars on the character values of students at SDN Gedanganak 01, Ungaran Timur District, Semarang Regency.

This research is expected to provide input for educators and related educational institutions, and scouting activities are very important because these activities can assist in the process of forming students' character values. In addition, the results of this study can help students in the formation of character values in accordance with the order of Indonesian cultural norms, and students avoid deviant behavior. 


\section{LITERATURE REVIEW}

a. Scouting

Permendikbud No. 62 of 2014 states that Extracurricular Activities are curricular activities carried out by students outside of learning hours for extracurricular activities and co-curricular activities, under the guidance and supervision of the education unit. According to Nawawi (1987:27) in Prihatin (2011:160), the types of extracurricular activities are school scouting, sports and arts, school hygiene and safety, student and scout savings (Tapelgram), school magazines, school stalls or canteens, and school health efforts. Endikbud Number 62 of 2014 states that there are two types of extracurricular activities, namely compulsory extracurricular activities and optional extracurricular activities.

Regulation of the Minister of Education and Culture Number 63 of 2014 concerning Scouting Education as a Compulsory Extracurricular Activity in Basic Education and Secondary Education. Scouting education is carried out to internalize the values of divinity, culture, leadership, togetherness, social, love of nature, and independence in students. It is hoped that the values in attitudes and skills as the content of the 2013 Curriculum and the content of Scouting Education can synergize in a coherent manner.

The Articles of Association and Bylaws (AD.ART) published by Kwarnas (2013:7) stated that scouting aims to form every scout:

1. Have a personality that is faithful, pious, has a noble character, has a patriotic spirit, obeys the law, is disciplined, uphold the noble values of the nation, has life skills, is physically and mentally healthy

2. Become a citizen who has the spirit of Pancasila, is loyal and obedient to the Unitary State of the Republic of Indonesia, and becomes a good and useful member of society, and can build himself independently and jointly be responsible for the development of the nation and state; have concern for other living beings.

b. Character

According to Sumantri in Heri Gunawan (2014: 31), the value of character is something that is contained in the human self (conscience) which is more based on moral principles, which are standards of beauty and efficiency or wholeness of heart.

Zainal Aqib (2012:40) argues that based on religious values, social norms, regulations/laws, academic ethics, and human rights principles, they have been grouped into five main character values, namely the values of human behavior in relation to God., self, fellow human beings, and the environment and nationality

According to Mulyana in Agus Zaenal Fitri (2012: 90), values include everything that is considered meaningful for a person's life whose considerations are based on the quality of right-wrong, good-bad, or beautiful-ugly, and whose orientation is anthropocentric or theocentric. For this reason, its value reaches all human activities, both relationships between humans, humans, and nature, and humans and God.

According to Agus Zaenal Fitri (2012: 90), there are 18 character values, namely: (1) Religious, (2) Honest, (3) Tolerance, (4) Discipline, (5) Hard Work, (6) Creative, (7) Independent, (8) Democratic, (9) Curiosity, (10) National spirit, (11) Love for the homeland, (12) Appreciating achievements, (13) Friendly/communicative, (14) Peaceful love, (15) Passionate Reading, (16) Care for the Environment, (17) Care for Social, (18) Responsibility. 
According to Mulyasa (2013:9), character value education aims to improve the quality of educational processes and outcomes that lead to the formation of the character and noble character of students as a whole, integrated, and balanced, in accordance with the competency standards of graduates in each educational unit. Character value education is essentially aimed at forming a nation that is strong, competitive, noble, moral, tolerant, cooperative, patriotic, dynamically developed, oriented to science and technology, all of which are inspired by faith and piety to God Almighty based on Pancasila (Pancasila). Heri Gunawan, 2014:30).

The Directorate of Education Personnel of the Ministry of National Education explained that the above-character education is meaningless if it is only the responsibility of the teacher to instill it in, students. We need the help of all components of society to realize the creation of the communication system required by the character-based education system. For this reason, Scouting as a non-formal educational activity is present as a solution to assist the government in shaping the character of students, one of which is by developing the values mentioned above.

Scouting extracurricular activities that have a relationship with student character values, namely: (1) Honest: determining the direction of the wind using a compass, (2) Discipline: UN activities (Army Rows), and making various line formations, among others, marching ranks, line, Angkare, big circle, and small circle, each team must follow the cues given by Pratama, (3) Friendly / communicative: make a yell and display it in front of the other team with the theme of the slogan "I like Scouts," (4) Peace of mind: a password task by looking for a word snake from a random letter, in this activity each team looks for a word from letters arranged randomly and forms a snake pattern that is running so as to form a sentence, (5) Responsibility: read the morse symbol, that is, each team is given a secret sentence, the sentence is written in morse code then each team must translate the secret message obtained

\section{RESEARCH METHOD}

The type of research used in this research is quantitative research. The experimental research design used is a quasi-experimental design. This research was conducted in class IV and class V at SDN Gedanganak 01, which is located at Jalan Diponegoro, Rt.01/Rw.01 Gedanganak, Ungaran Timur District, Semarang Regency.

The population in this study were members of the fundraisers at SDN Gedanganak 01, amounting to 51 people. The researchers took the entire population used as samples, namely as follows: 51 members of the SDN Gedanganak 01 fundraiser, East Ungaran District. The sampling technique used is the purposive sampling technique. Data collection techniques in this study using observation and documentation. Observations in this study were carried out to obtain the character values of each student. Observations were made twice, namely at the beginning before the behavior was given and at the end after the behavior was given. While the documentation method used is in the form of SKU, teacher diaries, and scout learning implementation plans about character values. There are two variables in this study, namely the independent variable and the dependent variable. The independent variable in this research is scouting extracurricular, and the dependent variable is character value.

Data analysis techniques in this study used descriptive statistics and inferential statistics. In this study, descriptive statistics were used to describe the sample data in the form of presenting data through tables, graphs, calculating means, medians, standard deviations, and calculating percentages - descriptive statistical calculation using SPSS 16 for windows program. At the same time, this technique is used to test the research hypothesis. The hypothesis of this research is as follows: 
$\mathrm{H}_{\mathrm{o}}=$ There is no effect of scouting extracurricular on the character values of the students of SDN Gedanganak 01, Ungaran Timur District, Semarang Regency.

$\mathrm{H}_{\mathrm{a}}=$ There is an influence of scouting extracurricular on the character values of the students of SDN Gedanganak 01, Ungaran Timur District, Semarang Regency.

To test the hypothesis, the independent t-test statistical technique was used. An independent t-test was used to compare two independent/uncorrelated samples-T-test analysis using the program spss 16 for windows.

\section{RESULTS AND DISCUSSION}

Based on descriptive statistics with the help of the SPSS 16 for the windows computer program, the results of the pretest can be seen in the following table.

Figure 4.1

Histogram Score Comparison of the Average Pretest and Posttest Character Values

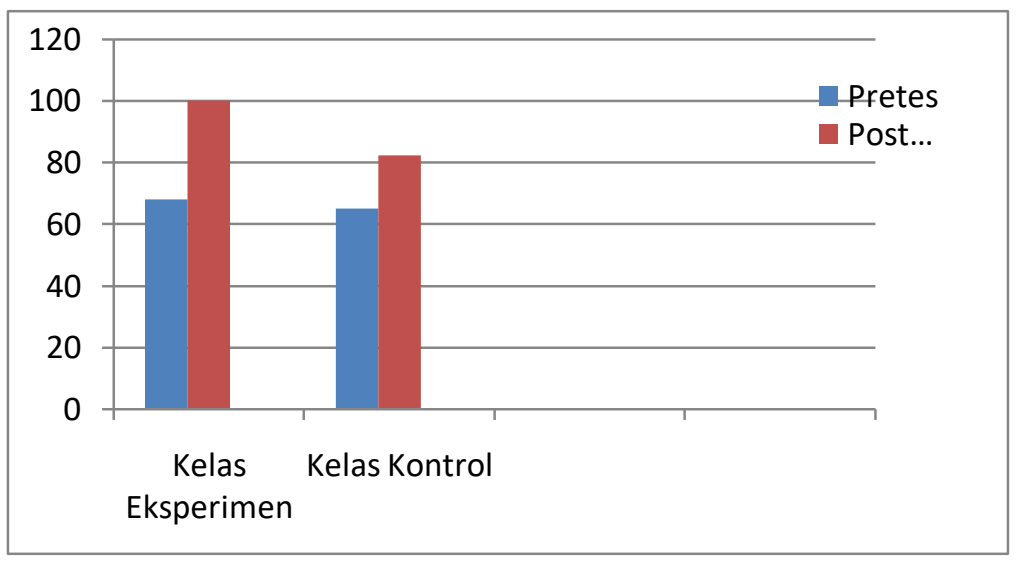

Based on the data above, it is known that the average pretest of the experimental class students is 74.67 while the control class students are 72.34. So, between the control class and the experimental class, the initial abilities are not much different. The results of the experimental class pretest on student character values obtained the lowest score of 67.86 and the highest score of 82.14. While in the control class, the lowest score was 65, and the highest score was 78.57. The posttest results of the experimental class who were in learning as usual and following extracurricular scouting activities obtained the lowest score of 89.29 , the highest score of 100, and the average value of 93.93. Meanwhile, in the control class, which only carried out learning as usual without participating in scouting extracurricular activities, the lowest score was 67.86. The results of the descriptive analysis show that there is a difference in the average value of students' character values between only carrying out daily learning without participating in scouting extracurricular activities with daily learning and participating in scouting extracurricular activities. The average value of students' character values in the experimental class is higher than the average value of students in the control class.

Based on the results of the analysis of the data above, it can be concluded that scouting extracurriculars have an effect on the character values of the students of SDN Gedanganak 01 class. The difference in the average pretest and posttest scores shows that there is an influence of scouting extracurriculars on students' character values. By 
participating in scouting extracurriculars, it will affect the character value of students compared to just daily learning.

Tests on the effect of scouting extracurriculars on the character values of elementary school students were also carried out using independent t-test analysis with pretest and posttest scores as covariates through the SPSS 16 for windows program. The hypothesis was carried out at a significance level of 5\% (0.05). The summary of the results of the analysis is presented in Table 4.1 below.

Table 4.1 Summary of $t$.test analysis results

\begin{tabular}{|l|c|c|c|c|c|}
\hline & \multicolumn{2}{|c|}{$\begin{array}{c}\text { Lavene's Test for } \\
\text { Equality of means }\end{array}$} & & \multicolumn{2}{c|}{$\begin{array}{c}\text { t-test for Equality of } \\
\text { means }\end{array}$} \\
\cline { 2 - 6 } & $\mathrm{F}$ & Sig & $\mathrm{T}$ & $\mathrm{Df}$ & $\begin{array}{c}\text { Sig. (2- } \\
\text { tailed) }\end{array}$ \\
\hline $\begin{array}{l}\text { Postes } \\
\text { character } \\
\text { value }\end{array}$ & 1,030 & 0,315 & 18,869 & 49 & 0,000 \\
& & & 18,895 & 48,959 & 0,000 \\
\hline
\end{tabular}

The criteria for testing the hypothesis of the t-test analysis in this study are $\mathrm{Ha}$ is accepted if the value of Sig (2-tailed) obtained is of the alpha level that is set, namely 5\% (0.05) and $\mathrm{H}_{0}$ is accepted if the value of Sig (2-tailed) is accepted. obtained > from the specified alpha level, namely 5\% (0.05). Based on Table 4.1 above, there is an independent Sig (2-tailed) t-test value of 0.000. Because the value of Sig (2-tailed) independent t-test $0.000 \leq(0.05)$, which means the value of Sig (2-tailed) 0.000 is smaller than alpha $(\alpha)$ which is 0.05 , then Ho is rejected, and Ha is accepted. So Ha, which reads that scouting extracurriculars affect the character values of elementary school students, is accepted. So it was concluded that scouting extracurricular had an effect on the character values of the students of SDN Gedanganak 01, Ungaran Timur District, Semarang Regency.

The results of testing the hypothesis that scouting extracurriculars have an effect on the character values of elementary school students have been proven. The effect of extracurricular scouting on the character values of elementary school students is indicated by the independent Sig t-test value of 0.000, which can be seen in the summary table of the results of the t-test analysis. So if the value of the independent Sig t-test (0.000) is smaller, it is equal to alpha $(\alpha)$ which is 0.05 , which means that scouting extracurriculars have an influence on the character values of elementary school students.

The results of this study are supported by the theories found previously. Fasli Djalal in P.C. Kahono (2010: 49) states that through scouting education, a child or teenager has good character, has the ability to carry out sustainable development, loves peace, and has a high sense of brotherhood. According to Suyanto (2009), character education is a way of thinking and behaving that characterizes each individual to live and work together both within the family, community, nation, and state.

\section{CONCLUSION}

Based on the data analysis and discussion that has been submitted, it can be concluded that the presence of scouting extracurriculars has an effect on the character values of the students of SDN Gedanganak 01. This means that more frequently participating in scouting extracurriculars will affect the character values of students' learning outcomes. Scouting extracurricular is proven to be more effective in influencing students' character values when compared to just learning in class. 
After analyzing the calculation of the t-test, the result is 0.000 , seen from the value of the Sig (2-tailed) independent t-test. Because the value of Sig (2-tailed) independent ttest 0.000 (0.05), which means the value of Sig (2-tailed) 0.000 is smaller than alpha $(\alpha)$ which is 0.05 . So Ha is accepted or proven true while Ho is rejected. So that the two variables are said to have an influence between scouting extracurriculars on the character values of students at SDN Gedanganak 01, Ungaran Timur District, Semarang Regency. The effect of extracurricular scouting on the character values of elementary school students is also shown by the average posttest score in each research class. The average value of the experimental class is 93.93, while the average value of the control class is 76.22. So it is evident that scouting extracurriculars have an effect on the character values of students.

\section{REFERENCES}

Aqib, Zaenal. 2012. Pendidikan Karakter Di Sekolah Mmebangun Karakter Dan Kepribadian Anak. Bandung: Yrama Widya.

Fitri, Agus Zaenal. 2012. Pendidikan Karakter Berbasis Niai dan Etika di Sekolah. Yogyakarta: Arruz Media

Gunawan, Heri. 2014. Pendidikan Karakter: Konsep dan Implementasi. Bandung: Alfabeta.

Kwarnas. 2013. Anggaran Dasar Dan Anggaran Rumah Tangga. Jakarta: Kwartir Nasional Gerakan Pramuka.

Keputusan Presiden No.238/1961 tentang Anggaran Dasar Gerakan Pramuka.

Mukson. 2008. Buku Panduan Materi Pramuka Penggalang. Semarang: PeTRAYA Offset.

Mulyasa. 2013. Manajemen Pendidikan Karakter. Jakarta: PT Bumi Aksara.

P.C. Kahono. 2010. Pramuka Membentuk Karakter Generasi Muda. Bandung: Puri Pustaka.

Permendikbud. 2 Juli 2014. Permendikbud Nomor 62 Tahun 2014 tentang Kegiatan Ekstrakurikuler pada Pendidikan Dasar dan Pendidikan Menengah, (online), (sdm.data.kemdikbud.go.id). Diakses tanggal 30 Agustus 2016.

Permendikbud. 28 Juli 2014. Permendikbud Nomor 63 Tahun 2014 tentang Pendidikan Kepramukaan sebagai Ekstrakurikuler Wajib, (online), (sdm.data.kemdikbud.go.id). Diakses tanggal 30 Agustus 2016.

Prihatin, Eka. 2011. Manajemen Peserta Didik. Bandung: Alfabeta. 